\title{
Mapping of semi-arid iron bearing red sands on emerged areas around lake marshes (Tablas de Daimiel, Spain) using hyperspectral DAIS 7915 spectrometer data
}

\author{
Asunción Riaza $\left({ }^{1}\right)$, Eduardo Garcia-Melendez $\left({ }^{2}\right)$, Mercedes Suárez $\left({ }^{3}\right)$, Andrea Hausold $\left({ }^{4}\right)$, \\ Ulrich Beisl $\left({ }^{4}\right)$ and Harald van der Werff $\left({ }^{5}\right)$ \\ (') Instituto Geológico y Minero de España (IGME), Madrid, Spain \\ $\left({ }^{2}\right)$ Área de Geodinámica Externa, Facultad de Ciencias Ambientales, Universidad de León, Spain \\ $\left(^{3}\right)$ Departamento de Geología, Universidad de Salamanca, Spain \\ $\left.{ }^{4}\right)$ DLR_German Aerospace Research Establishment, \\ Remote Sensing Data Centre, Oberpfaffenhofen, Wessling, Deutschland \\ $\left(^{5}\right)$ International Institute for Aerospace Survey and Earth Sciences (ITC), Enschede, The Netherlands
}

\begin{abstract}
Wetlands are particularly sensitive environments receiving attention from the natural sciences community due to their wealth of both flora and fauna, and often considered as natural parks. In the Tablas de Daimiel (La Mancha, Central Spain), Digital Airborne Imaging Spectrometer data (DAIS 7915) have been analyzed to map geological processes on areas around the receding wetland which have never been flooded by water in the past. Sediments permanently exposed to the atmosphere dehydrate and oxide, developing different mineralogical associations arranged on planation surfaces. Such planation surfaces are key in the geological knowledge of recent climate change and landscape evolution. Progressive iron oxide/hydroxide rate and decarbonation can be spectrally followed on the Holocene sands framing the current marshy area. Such mineralogical changes are geologically registered on flat surfaces at different heights over the receding shore of the paleolake. Interacting erosion and sedimentation processes are responsible for the development of the flat morphological surfaces with increasing dryness. Maps are built for four different morphological units consisting of planation surfaces following chronologically the receding marsh during the last 2000 years before the present. Interactive spectral responses of mineralogical associations are described on the imagery, field and laboratory spectra.
\end{abstract}

Key words hyperspectral - iron bearing minerals paleoclimate

Mailing address: Dr. Asunción Riaza, Instituto Geológico y Minero de España (IGME), Rios Rosas 23, 28003 Madrid, Spain; e-mail: a.riaza@igme.es

\section{Introduction}

The Las Tablas de Daimiel Natural Park frames a lake at the head of the river Guadiana draining to the Atlantic, settled in the large plain of La Mancha in Central Spain (fig. 1). This continental dry plain is subject to a Mediterranean dry, semi-arid climate with dry summer and winter and relatively short rainy seasons in fall and spring. Periods of drought are recurrent within 
the lapse of five years. It is a wetland with a linear morphology associated with alluvial river flats and hollows, resulting from the overflooding of the rivers Cigüela and Guadiana, joining and developing the Tablas, and the natural discharge of the underlying aquifer, through upwelling water at locations termed «ojos» (eyes). The study area is located at the Northern Las Tablas within the floodplain of the Ciguiela River, carrying silty and evaporitic sediments from Tertiary and Triassic gypsum materials underlying the upstream river course. The floodplain is formed by silty and clay sediments with organic matter and gypsum.

The recent sedimentological record of the quaternary deposits in the area points to recent harsh paleoenvironmental conditions (2500-2300 years before present) with diminishing humidity and lowering of groundwater levels (García Antón et al., 1986). Intensive use of groundwater for cereal crop irrigation has produced a serious descent on the groundwater level and coverage, an already irreversible environmental problem.

The spectral behaviour of iron bearing minerals has long been studied because of their widescale presence on lunar rocks (Hunt et al., 1971). Limonitic alteration was one of the first features attracting the attention of geological remote sensing (Rowan et al., 1977; Hunt and Ashley, 1979; Segal, 1983; Townsend, 1987). Weathering processes produce the same minerals as hydrothermal alteration processes (Buckingham and Sommer, 1983), and mask the spectral response of underlying rocks with coatings and internal mineralogical transformations (Lyon, 1997).

Space imagery is able to depict subtle variations in the reflectance properties of desert surfaces, which are indicative of changes in mineralogical composition. The intensity of the red colour of sands in Namibia (Logan, 1960) has been used as an indication of age in the dunes. In Australia, the intensity of dune reddening resulted in information on the distance from the source (El Baz and Prestel, 1980). Recent use of spectral response of iron bearing minerals in fluvial sediments is addressed to map the contamination of mine waste disposals (Farrand, 1997) using hyperspectral imagery. Traditional studies on laterite soils are conducted using the relative amount of iron oxides and hydroxides (Madeira et al., 1997) in humid rainforest climate.

Weathering of rock and soil surfaces responsible for the exterior mineral mixtures mainly

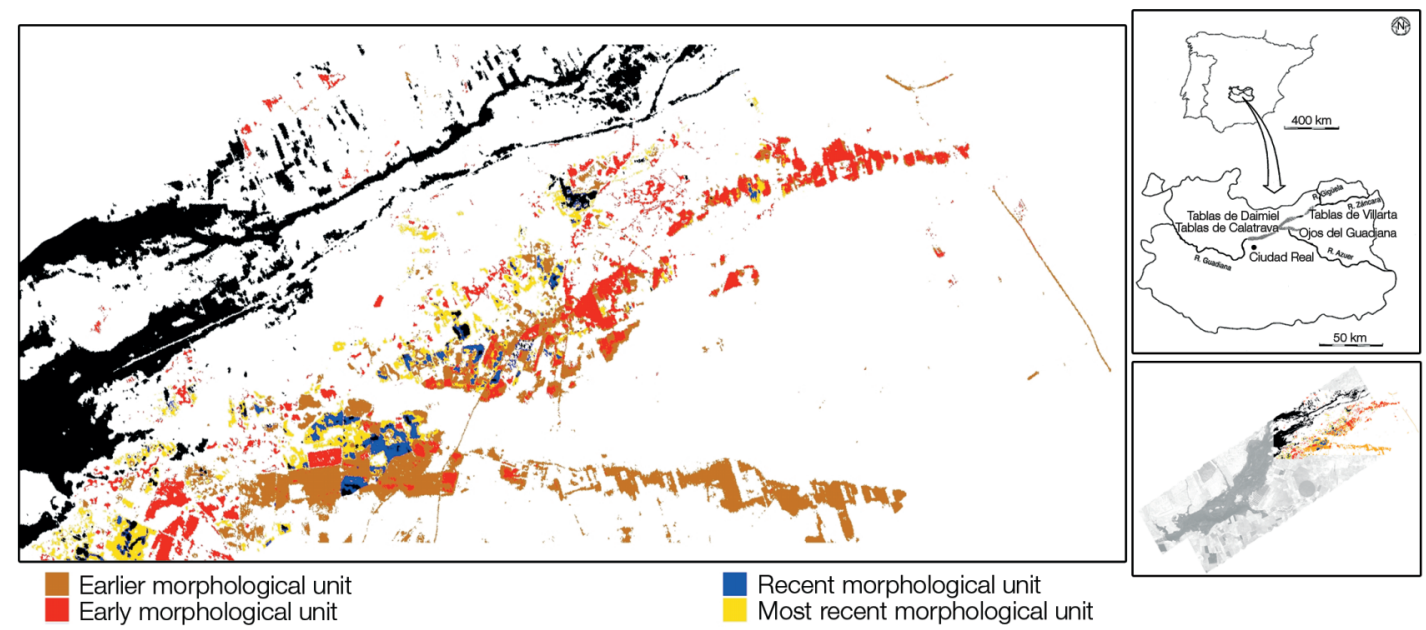

Fig. 1. Geological map composed from DAIS images indicating the main morphological units not previously mapped on emerged areas overprinting the Holocene underlying sands. Geographical location of the Tablas de Daimiel wetland and natural park in Central Spain and the northeastern area within DAIS data selected for mapping. 
contributing to the spectral response detected by remote sensors has gained attention among the remote sensing geological community (Pontual, 1987; Amos and Greenbaum, 1989; Riaza et al., 1995, 2000, 2001; Lyon, 1997; Younis et al., 1997). Different stages on weathering products and textures have been used for relative dating of lava flows of the same chemical and mineralogical composition with thermal infrared data (Kahle et al., 1988; Abrams et al., 1991).

The mixtures of iron and clay minerals produced by weathering alteration associated with posthercynian erosion paleosurfaces in the Duero Basin (Central Spain) developed under different paleoclimate have been mapped helping to model sediment patterns on various stages of the evolution of the sedimentary basin (Riaza et al., 2000). Climate-dependent saline soils, carbonate, organic matter and iron oxide surfaces have been mapped along different stages of flooding and emersion in the past 2000 years using hyperspectral data on prior work (Riaza et al., 2002). Emphasis is focused here towards the areas which have always been over the shoreline.

Lakes are environments particularly sensitive to climate changes, both actual and paleoclimate. Open system lakes fed by groundwater and seasonal runoff show a fluctuating shoreline. The most recent sediments hosting the Tablas de Daimiel wetland are Holocene sands arranged on several morphological units descending towards the marshy area. On a semiarid climate, the well ventilated and open sand deposits which are emerged, easily lose water. The iron bearing minerals decrease in hydroxides (goethite) to gain anhydrous ferric oxide (hematite) (Duchaufour, 1984) with the time of exposure to the atmosphere. As the wetland recedes, the whole sedimentological system on the riversides is demantled down towards the river. Four geomorphologic units not previously mapped can be traced through the imagery on the everemerged sands surrounding the marsh, based on their different height from the coastline, confirmed by fieldwork and aerial photography interpretation. These units are related to terraces, eolian deposits and desiccated areas. The earlier units are topographically high, and show a bright strong brown colour to the eye because of the comparatively higher hematite con- tents. Further loss of material by erosion and sedimentation produced by rain, runoff, and wind break the planation surfaces, which appear as both continuous and remanent sparse encased surfaces showing different stages of landscape development.

\section{Data set}

DAIS 7915 (Digital Airborne Imaging Spectrometer, VIS-NIR-TIR) hyperspectral Spectrometer data were recorded in July 2000, aiming at minimum vegetation vigour and maximum soil exposure. Flight altitude was decided to ensure the better sensor performance minimizing noise. Non-coherent noise was corrected after inflight calibration for DAIS (Strobl et al., 1996) to remove the sensor sensitivity effects on the 79 DAIS channels. DAIS data have a spatial resolution of $5 \mathrm{~m}$. Two overlapping flight lines were recorded and georeferenced (Schläpfer and Richter, 2002). Different spectral imaging processing tools were tested on atmospherically corrected data with a Radiative Transfer Code using a midlatitude summer profile (Richter, 1996; Richter et al., 2002) and field spectra from dark and light targets. Black body radiance surface and temperature were calculated using thermal infrared channels from field temperature measurements on a water body (Richter, 1996; Richter and Coll, 2002).

Field reflectance spectra were collected with a GER spectrometer for thematic analysis on geologically representative targets, to be used for interpretative image processing. Nonconsolidated soil samples were collected at different stages of the study of the imagery lead by image processing suggestions on sedimentology and time-dependent geomorphological processes resulting in mineralogical changes. Laboratory reflectance spectra were acquired on these samples using a Perkin-Elmer Lambda 6 spectrometer $(400-2400 \mathrm{~nm})$ provided with an integrating sphere using a standard of barium sulphate. Non-consolidated rock samples were dry-sieved before measurement. Munsell soil colour indexes (Munsell, 1990) were assigned in the laboratory to soil samples under a constant illumination source. 
$X$-ray diffraction (XRD) analysis was performed on selected non-consolidated rock samples to confirm field observations regarding mineralogical contents. Further spectral measurements were made on powdered samples after XRD aiming to ascertain spectral features which might appear on fine grained samples.

Image processing was conducted using ENVI (RSI, 2000) hyperspectral modules and reference spectral libraries.

The spectral interpretation of imagery, field and laboratory spectra was led by geological knowledge of the area and conventional geological field and laboratory survey. Interaction of all data and multidisciplinary analysis have been used throughout the study at every stage of progress.

\section{Digital image processing}

DAIS images were processed aiming to separate different sediments and minerals indicative of geological processes of palustrine, fluvial and eolian environments (fig. 1). Mosaics were composed with the two flight lines for synoptic view of the area, and for selection of areas of interest (fig. 1). Masks were built for densely vegetated areas using channels $17(0.7780 \mu \mathrm{m})$ and 13 $(0.7070 \mu \mathrm{m})$ for a red/near infrared ratio. Masks for water were also built using digital number 26 on channel $1(0.4900 \mu \mathrm{m})$ as threshold. A false colour composite with channels $19(0.8130 \mu \mathrm{m})$, $6(0.5850 \mu \mathrm{m})$ and $53(2.1330 \mu \mathrm{m})(\mathrm{BRG})$ was selected gathering information on wavelength ranges related to iron bearing minerals, and carbonate, for a preliminary estimation of the spectral variability in the area.

The six thermal infrared channels were used for an early evaluation of lithological variety (Riaza et al., 1998). Both Principal Components and Minimum Noise Fraction Transforms were useful to identify the main lithological regions indicating further hyperspectral image processing. Following field sedimentological observations suggested by previous image processing, masks were built using thresholds on selected minimum noise fraction transforms from thermal infrared DAIS channels to isolate geological units within the sands (Riaza et al.,
2002). Within the areas assigned to each unit, Pixel Purity Index and $n$-dimensional analysis were run on the 72 VNIR DAIS channels, helping to understand the geological spectral meaning of the various statistical populations among the sands (Boardman and Kruse, 1994).

\section{Laboratory spectra}

The Holocene red sands surrounding the Tablas de Daimiel wetland are sediments composed of sand with quartz as a main component. Comparison with USGS mineral spectral library on individual isolated minerals present on soil was made to identify the spectral features on the laboratory spectra possibly related to the minerals present on the mixture (fig. 2a). $X$-ray diffraction analysis showed no presence of clays on the red sands, but rather widespread carbonate. Spectra acquired on clay size powder from soil samples showed the presence of carbonate on most red sands.

Strong brown colour (Munsell, 1990) occurs on the earlier and topographically highest early morphological units rich in hematite resulting in deeper iron absorption in the visible and higher overall reflectance (fig. 2b). Dark brown colour on soil samples from recent units with more abundant iron hydroxide in the mineral mixture is associated with spectral lower overall reflectance.

The early topographically higher morphological units rich in hematite display a smooth absorption at $850 \mathrm{~nm}$ because of the presence of ferric cation (Hunt et al., 1971). Hematite is also shown by the inflexion point at $548 \mathrm{~nm}$ in the visible (fig. 2b). The recent units display a less steep straight line response in the visible and lower overall reflectance, due to the more abundant iron hydroxide. Recent units also show a relatively emphasized shape at $2300 \mathrm{~nm}$ due to carbonate (Hunt and Salisbury, 1971).

\section{DAIS spectral response}

Spectral profiles are extracted from the areas finally mapped on DAIS imagery (fig. 1). The spectra shown in this chapter are highly 

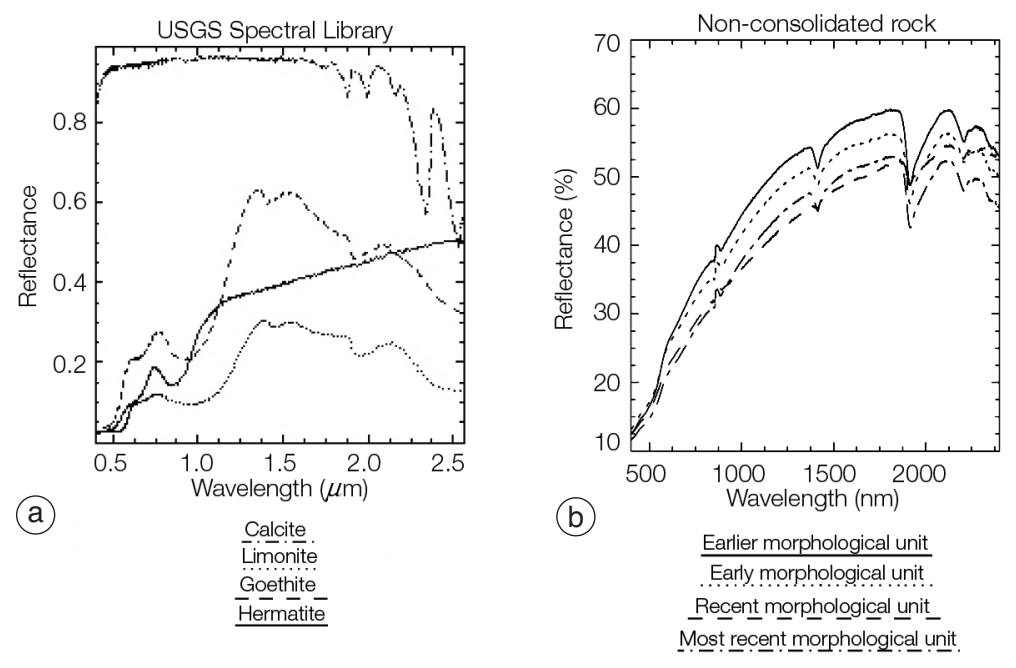

Fig. 2a,b. a) Spectra of the main minerals present in the sediments of the area of study related to dehydration and oxidation of sands exposed to the atmosphere (United States Geological Survey Spectral Library). b) Laboratory spectra from field non-consolidated rock samples measured with a Perkin Elmer Lambda 6 Spectrometer on representative morphological units.
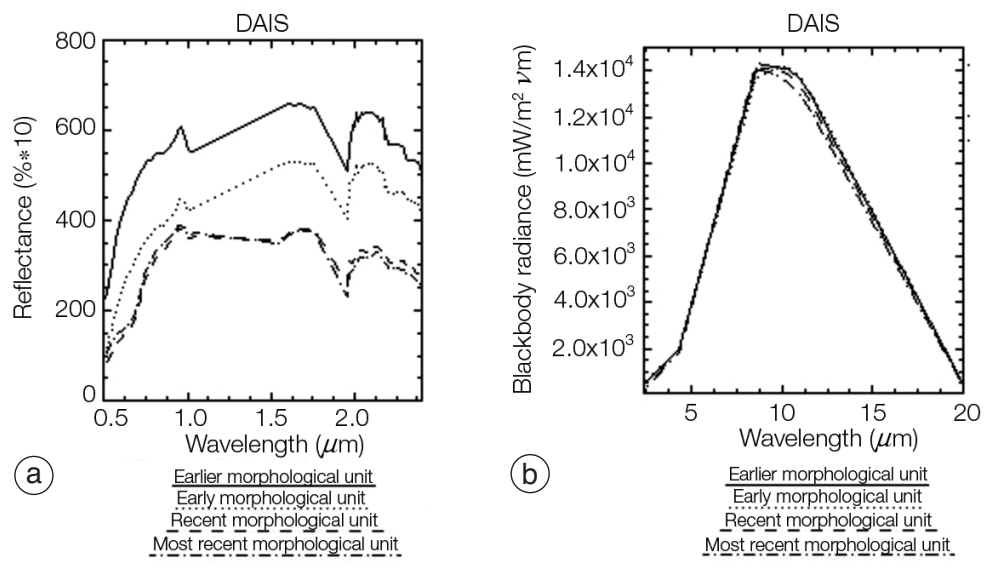

Fig. 3a,b. a) VNIR spectral profiles from DAIS images from areas representative of morphological units on the map in fig. 1. b) TIR spectral profiles from DAIS images from areas representative of morphological units on the map in fig. 1.

mixed areas both in geological and land use terms. The four morphological units are sands containing mixtures of iron bearing minerals which can be spectrally traced by relative transitional mineralogical abundances produced by increasing dehydration and decarbonation with time. The sands are cultivated with vineyard crops, regularly spaced plants which cannot be spectrally removed from data with a spatial resolution of $5 \mathrm{~m}$. Crops diminish near the natural 
park and the land use changes to an intermittent ploughed and natural vegetation pattern, where the recent and most recent units occur. The following spectral observations must be considered trends of spectral behaviour. No single mineral influence is expected to be identified.

DAIS images present a distinguishing response between once flooded and everemerged areas surrounding the wetland (Riaza et al., 2002). Spectra of all the emerged areas, whether sand deposits or continental aprons or fluvial deposits, show depressions in the visible mainly due to the presence of iron bearing minerals (fig. 3a).

The wide depression in the visible related to iron bearing minerals on red everemerged sands is more pronounced, consistent with their strong brown colour (fig. 3a). In all of the mapped units, early emerged sands display the highest overall reflectance. The areas which were once flooded are less expressive in the visible (Riaza et al., 2002) because of the presence of organic matter.

The areas emerged display a shoulder between 2.2-2.3 $\mu \mathrm{m}$ non-existent on the flooded areas. This might suggest abundance of clays, which is not confirmed by XRD mineralogical analysis or by sedimentological expectations. Widespread carbonate is more likely to contribute to this spectral feature.

Four systems of reddish sands arranged on four morphological units have been spectrally identified based on different iron minerals related to variable time of exposure to the atmosphere and weather conditions. Such morphological units can be distinguished in the field and spectra by intensity of reddening that is directly related to age (figs. 2a and 3a). The intensity of redness in semi-arid environments is related to the increasing hematite contents (Duchaufour, 1984) by loss of water in the environment. Goethite decreases in the iron bearing mineral mixtures with increasing dryness. Such mineralogical changes are spectrally recorded by the imagery. The topographically upper and early morphological units show a shoulder on $0.85 \mu \mathrm{m}$ which would be related to the ferric ion from hematite (Hunt et al., 1971). This is not present on the lower and recent morphological units.

The two recent morphological units display a smooth depression between $0.70-0.74 \mu \mathrm{m}$ due to the iron hydroxide goethite (Hunt et al.,
1971). Vegetation has been discarded as contributing to this feature, since vineyard crops are homogeneously distributed.

Carbonate is also suggested on the two recent morphological units by a subtle $2.3 \mu \mathrm{m}$ absorption or weakened shape in comparison with spectra from hematitic surfaces. This absorption is not present on spectral profiles of the two earlier units, which have been exposed long enough to be decarbonated. Carbonate is widespread throughout the area both in emerged and flooded areas. Imagery is too noisy on the near infrared to be able to show carbonate-related absorption, which is relatively weak on the laboratory spectra. Spectral profiles on DAIS imagery do not depict a clear spectral response due to the low energy available for the fourth detector on the 2000-2500 nm wavelength range, but tendencies of more abundant carbonate are suggested on the early more hydrated units.

The thermal infrared channels from DAIS images display a varied spectral response for the four morphological units (fig. 3b). The recent units rich in hydroxides show a higher radiance surface at $8.58 \mu \mathrm{m}$ decreasing comparatively to the older units at longer wavelength ranges. Further laboratory spectral analysis is necessary to explain diversity on the spectral response.

\section{Conclusions}

Morphological units developed over sediments not previously mapped have been outlined. Such morphological units are planation surfaces which developed during a certain period of time. The four morphological units have been mapped using DAIS images, and their spectral properties described in terms of geological processes resulting in different mineral mixtures. Image processing has helped to lead the identification by conventional geological survey. Further image processing produced the final map.

Hyperspectral imagery has been able to distinguish four morphological units descending towards a receding wetland due to different iron bearing mineral contents associated with variable times of exposure to the atmosphere and 
increasingly dry weather conditions. Mineralogical variations on iron oxides and hydroxides developed when sediments are emerged are easily recorded in the visible wavelength range.

The older units rich in hematite and poor in carbonate depict a distinguishing convex shape in the visible with a shoulder at $850 \mathrm{~nm}$ due to the ferric ion from hematite. On the contrary, the younger less dehydrated units, display a smooth depression between 700-740 nm likely due to goethite, and a subtle absorption or flattened response at $2300 \mathrm{~nm}$ because of the presence of carbonate. Both features are displayed by imagery and laboratory spectra.

DAIS thermal infrared, particularly sensitive to topography, orientated the first image processing to depict spectrally variable areas. A more detailed map of the emerged morphological units has been drawn from the imagery, with further hyperspectral image processing in the 72 VNIR channels on selectively masked areas for wide geological areas outlined from Thermal Infrared.

\section{Acknowledgements}

The Fifth Framework Program, Improvement of Human Potential, Access to Research Infrastructures (contr. HPRI-CT-1999-00075, ref HS2000-ES1) and the Science and Technology Commission in Spain (CYCIT REN 00204433-C02-01) funded this work. Luis Pascual assisted with the use of the laboratory spectrometer. Thanks are due to S. Martin Alfageme and Iñigo Martin for software and hardware assistance (STIG, University of Salamanca).

\section{REFERENCES}

Abrams, M., E. Авbott and A. Kahle (1991): Combined use of visible, reflected infrared, and thermal infrared images for mapping Hawaiian lava flows, J. Geophys. Res., 96 (B1), 475-484.

Amos, B.J. and D. GreEnBAum (1989): Alteration detection using TM imagery. The effects of supergene weathering in an arid climate, Int. J. Remote Sensing, 10 (3), 515-527.

Botrdman, J.W. and F.A. Kruse (1994): Automated spectral analysis: a geologic example using AVIRIS data, north Grapevine Mountains, Nevada, in Proceedings of the Tenth Thematic Conference on Geologic Remote
Sensing, Environmental Research Institute of Michigan, Ann Arbor, MI, I-407-I-418.

BuCKIngham, W.F. and S.E. Sommer (1983): Mineralogical characterization of rock surfaces formed by hydrothermal alteration and weathering. Application to remote sensing, Econ. Geol., 78, 664-674.

Duchaufour, Ph. (1984): Edafogénesis y Clasificación (Masson Ed., Barcelona), tomo 1, pp. 493.

El BAZ, F. and D.J PREstel (1980): Desert varnish on sand grains from the Western Desert of Egypt: importance of the clay component and implications to Mars, in $\mathrm{Lu}$ nar and Planetary Science XI, Houston, Texas (Lunar and Planetary Institute), Part I, 254-256.

FARRAND, W.H. (1997): Identification and mapping of ferric oxide and oxyhydroxide minerals in imaging spectrometer data of Summitville, Colorado, U.S.A., and the surrounding San Juan Mountains, Int. J. Remote Sensing, 18 (7), 1543-1552.

García Antón, M., C. Morla, B. Ruiz Zapata and H. Sais OLLERO (1986): Contribución al conocimiento del paisaje vegetal Holoceno en la Submeseta Sur Ibérica: análisis polínico de sedimentos higroturbosos en el Campo de Calatrava (Ciudad Real, España), in Quaternary Climate in Western Mediterranean, edited by F. LÓPEZ VERA (Universidad Autónoma de Madrid Publications).

Hunt, G.R. and R.P. Ashley (1979): Spectra of altered rocks in the visible and near-infrared, Econ. Geol., 74, 1613-1629.

HuNT, G.R. and J.W. SALiSBURY (1971): Visible and nearinfrared spectra of minerals and rocks, II. Carbonates, Mod. Geol., 2, 23-30.

Hunt, G.R., J.W. SAlisbury and J. Lenhof (1971): Visible and near-infrared spectra of minerals and rocks, III. Oxides and hydroxides, Mod. Geol., 2, 191-205.

Kahle, A.B., A.R. Gillespie, E.A. Abbott, M.J. Abrams, R.E. WALKer and G. Hoover (1988): Relative dating of Hawaiian lava flows using multispectral themal infrared images: a new tool for geologic mapping of young volcanic terranes, J. Geophys. Res., 93 (B12), $15239-15251$.

Logan, R.F. (1960): The Central Namib Desert, N.A.S., N.R.C. Publ., 785, pp. 162.

LYON, R.S.P. (1997): Weathering products and other coatings on rock surfaces: problems with airborne scanner imagery (RSS97-112), in 23rd Annual Conference and Exhibition of the Remote Sensing Society, 2-4 September 1997, The University of Reading, 54-59.

Madeira, J., A. Bedidi, B. Cervelle, M. Puget and N. FLAY (1997): Visible spectrometric indices of hematite $(\mathrm{Hm})$ and goethite $(\mathrm{Gt})$ content in lateritic soils: the application of a Thematic Mapper (TM) image for soilmapping in Brasilia, Brazil, Int. J. Remote Sensing, 18 (13), 2835-2852.

Munsell, Color Co. (1950, revised 1990): Munsell Soil Color Charts, Munsell Color, Macbecth Division of Kollmorgen Corporation, Baltimore, MD.

Pontual, A. (1987): The effect of weathering minerals on the spectral response of rocks in Landsat Thematic Mapper imagery, in Proceedings of the 13th Annual Conference of the Remote Sensing Society, 7-11 September 1987, Nottingham, 549-558.

Riaza, A., R. Mediavilla, J.I. Santisteban, P. Villar and S. MARtin Alfageme (1995): Regolitos en una cuenca 
terciaria. Propiedades espectrales según su mineralogía en función de la evolución climática, in Coloquio Internacional sobre Propiedades Espectrales y Teledetección de los Suelos y Rocas del Visible al Infrarrojo Medio, 24-27 April 1995, La Serena (Chile), 100-104.

Riaza, A., H. Kaufmann, A. Zock and A. Müller (1998): Mineral Mapping in Maktesh-Ramon (Israel) using DAIS 7915, in Proceedings 1st Workshop on «Imaging Spectroscopy», 6-8 October 1998, Zürich, Switzerland, 365-374.

Riaza, A., R. Mediavilla and J.I. Santisteban (2000): Mapping geological stages of climate-dependent iron and clay weathering alteration and lithologically uniform sedimentary units using Thematic Mapper imagery, Int. J. Remote Sensing, 21 (5), 937-950.

Riaza, A., P. Strobl, A. Müller, U. Beisl and A. Hausold (2001): Spectral mapping of rock weathering degrees on granite using hyperspectral DAIS 7915 Spectrometer Data, Int. J. Appl. Earth Obs. Geoinf., 3 (4), 2001, 345-354.

Riaza, A., R. Mediavilla, E. García-Meléndez, M. SuÁrez, A. Hausold, U. Beisl and H. van der WerfF (2002): Mapping paleoflooded areas on evaporite playa deposits over sandy sediments (Tablas de Daimiel, Spain) using hyperspectral DAIS 7915 and ROSIS spectrometer data, in Proceedings of the 1st International Symposium Recent Advances in Quantitative Remote Sensing, Torrent, Spain, 16-20 September 2002; in Recent Advances in Quantitative Remote Sensing, edited by J.A. SobRINO, 371-379.

RICHTER, R. (1996): Atmospheric correction of DAIS hyperspectral image data, Comput. Geosci., 22 (7), 785-793.
RICHTER, R. and C. COLL (2002): Bandpass-resampling effects for the retrieval of surface emissivity, Appl. Optics, 41, 3523-3529.

RICHTER, R., A. MüLLER and U. HEIDEN (2002): Aspects of operational atmospheric correction of hyperspectral imagery, Int. J. Remote Sensing, 23 (10), 145-158.

Rowan, L.C., A.F.H. Goetz and R.P. Ashley (1977): Discrimination of hydrothermally altered and unaltered rocks in the visible and near infrared multispectral images, Geophysics, 42 (3), 522-535.

RSI (2000): ENVI, the Environment for Visualizing Images Manual (Research Systems, Inc.).

SCHLÄPFER, D. and R. RICHTER (2002): Geo-atmospheric processing of airborne imaging spectrometry data, Part 1. Parametric ortho-rectification process, Int. J. Remote Sensing, 23 (13), 2609-2630.

SEGAL, D.B. (1983): Use of Landsat multispectral scanner data for the definition of limonitic exposures in heavily vegetated areas, Econ. Geol., 78, 711-722.

Strobl, P., R. Richter, F. Lehman, A. Müller, B. Zhukov and D. OerTel (1996): Preprocessing for the Digital Airborne Imaging Spectrometer DAIS 7915, in SPIE's AEROSENSE '96 Conference, April 8-12, 1996, Orlando, SPIE Proc., 2758, 375-382.

TownsEND, T.E. (1987): Discrimination of iron alteration minerals in visible and near-infrared reflectance data, J. Geophys. Res., 92 (B2), 1441-1454.

Younis, M.T., A.A., GilaberT and J. Meliá (1997): Weathering process effects on spectral reflectance of rocks in a semi-arid environment, Int. J. Remote Sensing, 18 (16), 3361-3377. 